\title{
Folate absorption
}

\author{
A. V. HOFFBRAND
}

From the Department of Haematology, Royal Postgraduate Medical School, London

Folic acid, or pteroylglutamic acid, is the parent substance of a large group of related compounds called 'folates'. All folate compounds have the same basic molecular structure consisting of three parts: pteridine, para-aminobenzoate (these two together forming a pteroyl group), and L-glutamic acid (Fig.1). Pteroylglutamic acid itself is a stable, watersoluble compound with a molecular weight 441.4 ; it forms yellow, spear-shaped crystals. Though this was the form of the vitamin first crystallized from natural materials (Mitchell, Snell, and Williams, 1941), pteroylglutamic acid as such is only a minor component (less than $1 \%$ ) of natural folates. The folates that do occur in plants and animals and therefore form the bulk of normal dietary folate differs from pteroylglutamic acid in that (1) they are usually reduced to the di- or tetrahydrofolate state at positions $5,6,7$, and 8 in the pteroyl portion; (2) they usually contain a methyl or formyl group at position 5, or a formyl at position 10 in the pteroyl portion; (3) they usually contain a chain of three or more glutamic acid residues linked to each other by gamma peptide bonds (Fig. 1).

Most studies of folate absorption have been carried out using pteroylglutamic acid because this compound is stable and is commercially available in pure form, both radioactively labelled as tritiated pteroylglutamic acid, and non-labelled. It is likely that the events that take place during absorption of natural folates differ in several respects from those

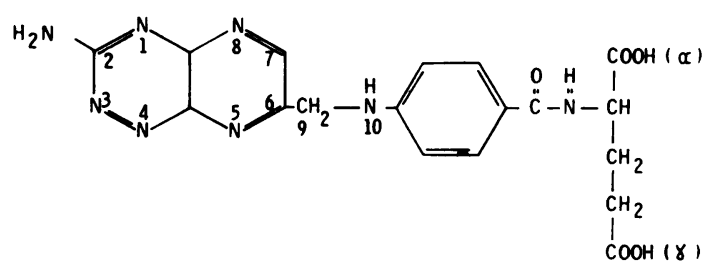

Fig. 1 Formula for folic acid (pteroylglutamic acid).

Dietary folates may contain: (1) Additional hydrogen atoms at positions 7 and 8 (dihydrofolate) or 5, 6, 7, and 8 (tetrahydrofolate). (2) A formyl group at $N_{5}$ or $N_{10}$ or a methyl group at $N_{5}$. (3) Additional glutamate moieties attached to the $\gamma$-carboxyl group of the glutamate moiety. that occur during pteroylglutamic acid absorption. $\stackrel{\vec{\circ}}{\circ}$ It is impossible, however, to give a clear detailed $\vec{\omega}$ picture of the absorption process of either form of? folate since there are wide disagreements in this field, both in the evidence produced by differentis groups and in their interpretation. These differences or may stem partly from technical difficulties. Forinstance, many measurements are made with rela- .9 tively inaccurate microbiological assays. Moreover,o most folate compounds are not available pure and are unstable; the only radioactive forms of folatec available are labelled with $\beta$ emitters $\left({ }^{14} \mathrm{C}\right)$ or $\left({ }^{3} \mathrm{H}\right)$, כै which means that studies of faecal excretion areฏ difficult and studies using whole body counting are $₹$ impossible. Finally, no studies have been carried out $\overrightarrow{0}$ using foods containing isotopically labelled folate. $§$.

The aim of this paper will be first to summarize what is known about the absorption of ptero glutamic acid, both in man and in experimental animals, second to describe what is known of then absorption of natural folates in man, and finally, toळ enumerate those clinical syndromes in which malabsorption of folate is thought to occur. Causes of folate deficiency other than malabsorption and the methods of diagnosis of folate deficiency have been the subjects of a number of recent reviews (Mollin and Waters, 1968; Chanarin, 1969; Hoffbrand and Peters, 1970; Herbert, 1970; Waxman, Corcino, andoHerbert, 1970) and are not discussed here.

\section{Absorption of Pteroylglutamic Acid}

\section{HUMAN STUDIES}

Methods

Microbiological assays with Streptococcus faecalis and Lactobacillus casei are widely used in the study? of folate absorption and it is therefore essential too know the growth characteristics of these bacteria onw different forms of folate in order to interpret the results. Table I shows the response of these organismso to different folate compounds.

Pteroylglutamic acid absorption was originally. studied by measuring urinary excretion of folate microbiologically with $S$. faecalis after an oral dose of the compound (Denko, Grundy, Wheeler 


\begin{tabular}{|c|c|c|}
\hline & L. casei & S. faecalis \\
\hline $\begin{array}{l}\text { Pteroylglutamic acid } \\
\text { 5-Methyltetrahydropteroylglutamic acid } \\
\text { Pteroyldiglutamic acid } \\
\text { Pteroyltriglutamic acid } \\
\text { Pteroylpolyglutamic acid ( }>3 \text { glutamate } \\
\text { moieties) }\end{array}$ & $\begin{array}{l}+ \\
+ \\
+ \\
+ \\
-\end{array}$ & $\begin{array}{l}+ \\
\overline{+} \\
- \\
-\end{array}$ \\
\hline
\end{tabular}

Table I Growth of $\mathrm{L}$. casei and $\mathrm{S}$. faecalis on different folate compounds

$1+=$ growth, $-=$ no growth.

Henderson, Berryman, Friedemann, and Youmans, 1946; Swendseid, Bird, Brown, and Bethell, 1947). Girdwood (1953) adapted this technique to distinguish more accurately between conditions of folate malabsorption and conditions of deficiency without malabsorption by comparing excretion of folate after oral and parenteral doses of pteroylglutamic acid. A more reliable method for routine clinical purposes was subsequently developed, in which the rise in serum pteroylglutamic acid level is measured with $S$. faecalis following an oral dose of pteroylglutamic acid (Denko, 1951; Spray and Witts, 1952; Chanarin, Anderson, and Mollin, 1958). The patient is saturated with folate before the test to ensure that absorbed folate is not rapidly removed from plasma by folate-deficient tissues.

Studies in man have also been performed by using the double-lumen tube technique, ie, perfusing a given segment of small intestine and measuring folate absorption by the difference in concentration between folate infused and withdrawn (Hepner, Booth, Cowan, Hoffbrand, and Mollin, 1968); by assessing the ability of a patient with megaloblastic anaemia due to folate deficiency to respond haematologically to physiological doses of pteroylglutamic acid given by mouth; and by measuring the rise in plasma radioactivity, and urinary and/or faecal excretion of radioactivity after an oral dose of tritiated pteroylglutamic acid (Anderson, Belcher, Chanarin, and Mollin, 1960; Kinnear, Johns, MacIntosh, Burgen, and Cameron, 1963; Klipstein, 1963; Paterson, David, and Baker, 1965; Kremenchuzky, Musso, Hoffbrand, and Rochna Viola, 1967; Yoshino, 1968a).

\section{Findings}

Pteroylglutamic acid is rapidly absorbed from the duodenum and jejunum and a rise in blood folate level occurs as soon as $\mathbf{1 5}$ minutes after an oral dose. Between $60 \%$ and $80 \%$ of a single dose is absorbed whether this is small $(25-200 \mu \mathrm{g})$ or large $(1-15 \mathrm{mg})$. When pteroylglutamic acid is infused at a constant rate into the jejunum, the proportion absorbed is the same until very high concentrations $(10 \mu \mathrm{g} / \mathrm{ml})$ are reached when the proportion absorbed falls (Hepner et al, 1968). Folate is comparatively poorly absorbed from the lower small intestine, the fall in proportion absorbed from the upper to lower jejunum being much steeper for pteroylglutamic acid than for glucose (Hepner et al, 1968). Folate is not absorbed from the large intestine (otherwise, folate-producing colonic bacteria would be able to supply the body with considerable amounts of the vitanin).

There is no definite evidence whether or not pteroylglutamic acid is absorbed by an active, energy requiring process in man. Most of a dose of $1 \mathrm{mg}$ enters the portal blood unchanged (Whitehead and Cooper, 1967) and the pteroylglutamic acid released from a large dose of pteroylpolyglutamic acid also enters the portal blood intact (Butterworth, Baugh, and Krumdieck, 1969). Possible evidence that pteroylglutamic acid is absorbed against a concentration gradient in man is that there is no inhibition of pteroylglutamic acid absorption when the blood folate is raised by parenteral administration of pteroylglutamic acid (Hepner et al, 1968), but the exact form of folate on the mucosal side of the jejunal brush border in such an experiment is uncertain.

Baker, Frank, Feingold, Ziffer, Gellene, Leevy, and Sobotka (1965) suggested that pteroylglutamic acid in doses as high as $5 \mathrm{mg}$ was reduced and methylated during passage through the small intestine, but they did not exclude the possibility that the compound was absorbed unchanged and then converted into 5-methyltetrahydrofolate (the form of folate in normal plasma) by the liver or exchanged with liver 5-methyltetrahydrofolate. Most workers consider that such large doses of pteroylglutamic acid are absorbed intact. However, it is possible, though not established, that there is a minor degree of conversion of low doses of pteroylglutamic acid to 5-methyltetrahydrofolate during its transfer through the jejunal mucosa. As discussed below, there is stronger evidence for conversion of partly reduced folate to 5-methyltetrahydrofolate by the jejunum (Perry and Chanarin, 1970).

Baker, Frank, and Sobotka (1964) suggested that pteroylglutamic acid is conjugated to the triglutamate form during absorption but there has been no support for this hypothesis.

Perhaps the best evidence that absorption of pteroylglutamic acid in man involves a specific process is provided by the observations of Luhby, Eagle, Roth, and Cooperman (1961) and Lanzkowsky, Erlandson, and Bezan (1969) of individuals with specific malabsorption of folates, including pteroylglutamic acid (see below) but, as yet, there is no definite evidence that this process requires energy. 


\section{ANIMAL STUDIES}

Most studies have been performed in the rat or hamster. The jejunum is the principal site of folate absorption in these animals and absorption is maximum at a pH around 6.0 (Elsborg, 1970; Smith, Matty, and Blair, 1970). It is again uncertain whether or not pteroylglutamic acid is actively transferred across the small intestine. Burgen and Goldberg (1962) using in-vivo perfused loops, Herbert and Shapiro (1962) and Herbert (1967) using the everted sac technique, and Hepner (1969) using the in-vivo tied loop system all conclude that pteroylglutamic acid is actively transported by the jejunum at low doses and passively transferred at higher doses. On the other hand, Turner and Hughes (1962), Spencer and Bow (1964), and Yoshino (1968b) all conclude, on the basis of everted sac studies, that pteroylglutamic acid is passively absorbed across the jejunum of the rat at all doses. In a recent careful study, albeit with the everted sac preparation, Smith et al (1970) conclude that transport of pteroylglutamic acid at concentrations ranging from $1 \times$ $10^{-7} \mathrm{M}$ to $1 \times 10^{-6} \mathrm{M}$ across the jejunal mucosa of the rat occurs by a saturable process, partly by passive diffusion and partly by glucose-stimulated solvent drag with water flow.

All workers agree that transport of pteroylglutamic acid across the ileum of the rat is passive at all concentrations.

On the basis of differential microbiological assays, Cohen (1965) postulated that pteroylglutamic acid was converted to 5-methyltetrahydrofolate during transport across rat jejunum, but these studies are inconclusive since bacterial synthesis of the methylfolate in the (unsterile) everted sac preparation was not excluded. A possible point in favour of Cohen's conclusion is the observation by two groups (Burgen and Goldberg, 1962; Hepner, 1969) that methotrexate, which inhibits reduction of pteroylglutamic acid, also inhibits absorption of pteroylglutamic acid in the rat. This could be interpreted to indicate that reduction to the tetrahydrofolate form is a key, ratelimiting reaction in the pteroylglutamic acid absorption process. This is unlikely, however, in view of the convincing demonstration by Smith et al (1970) that pteroylglutamic acid is largely unchanged after transport across the rat jejunal mucosa in vitro. Instead inhibition by methotrexate might indicate that pteroylglutamic acid and methotrexate compete for the same absorptive mechanism. Methotrexate has indeed been shown to interfere with transport of pteroylglutamic acid into haemopoietic cells (Das and Hoffbrand, 1970). Yoshino (1968b) could not demonstrate an effect of methotrexate on pteroylglutamic acid absorption in the rat, however, so no conclusion can yet be reached on this point.

\section{Human Absorption of Natural Folates}

FORMS OF FOLATE

The small intestine in the human adult is presentect. with folate from three sources-from the diet, from bile, and from sloughed intestinal cells.

\section{Dietary folate}

The normal adult western diet contains about $600-700 \mu \mathrm{g}$ of folate daily and approximately three-n quarters of this is in the polyglutamate form $\overrightarrow{0}$ (Butterworth, Santani, and Frommeyer, 1963; Chanarin, Rothmann, Perry, and Stratfull, $1968 ; \vec{\omega}$ Hurdle, Barton, and Searles, 1968). The uncooked diet contains much larger amounts of folate but up? to $100 \%$ of this may be lost when high temperaturesc and large amounts of water are used in cooking or Major compounds in the diet are 5-methyl-, $\dot{\sigma}$ 5-formyl-, and 10-formyl-tetrahydropteroylpoly-o glutamates. The polyglutamate forms with more응 than three glutamate moieties are not microbio- logically active until they have been hydrolysed to the simpler tri, di-, or monoglutamate forms, when they can be assayed with $L$. casei, and are termed 'free' (Table I).

\section{Biliary folate}

S. Baker, Kumar, and Swaminathan (1965) first demonstrated an enterohepatic circulation for folate in man. They found a mean folate level of $32.6 \mathrm{ng} / \mathrm{ml}$ in the duodenal juices of eight normal subjects who응 had a mean serum folate level of $4.6 \mathrm{ng} / \mathrm{ml}$; apparent- $\varrho$ ly between 60 and $90 \mu \mathrm{g}$ of folate enters the bile each $\overrightarrow{\hat{O}}$ day. Biliary folate is mainly in the form of 5-methyl-3 tetrahydrofolate and formylfolates (Bernstein, Gutstein, Weiner, and Efron, 1970b; Pratt and Cooper, 1971).

\section{Folate in sloughing intestinal cells}

This is extremely difficult to quantitate. Small amounts of folate are present in human jejunal mucosa and these are probably mainly in the free form of the vitamin when they reach the intestinal lumen.

ABSORPTION OF PTEROYLPOLYGLUTAMATES Two groups have synthesized labelled pteroylpolyglutamates and studied their absorption both micro- 요 biologically and by radioactive techniques (Butter- $\mathrm{W}$ worth et al, 1969; Godwin and Rosenberg, 1970; Rosenberg and Godwin, 1971). All other studies $\frac{0}{\tau}$ have been carried out using microbiological assay of $\frac{}{\Phi}$ serum or urine after oral doses of natural folates. Early studies using $S$. faecalis as a test organism $T_{T}$ suggested that very little folate could be absorbed $\frac{0}{\Phi}$ from yeast (Spray, 1952). It is now established, 
however, that significant amounts of folate are absorbed from the higher pteroylpolyglutamates of yeast and other foods.

The folate entering the blood stream after feeding pteroylpolyglutamates is active for $L$. case $i$ and has been shown to be in the pteroylmonoglutamate form (Butterworth et al, 1969). This indicates that hydrolysis has occurred during absorption. Recent work from many laboratories has failed to support the earlier suggestion of Cooperman and Luhby (1965) that pteroylpolyglutamates can be absorbed intact. The proportion of a dose of yeast pteroylpolyglutamates that can be absorbed has been estimated to be similar to that of pteroylglutamic acid at a dose of about $200 \mu \mathrm{g}$, while at higher doses absorption has been estimated to be only one-third that of pteroylglutamic acid (Streiff and Rosenberg, 1967; Hoff brand and Necheles, 1968; Perry and Chanarin, 1968; Hoffbrand and Peters, 1970). It is likely that the compounds with the greatest number of glutamate moieties are least well absorbed (Butterworth et al, 1969).

Most studies of pteroylpolyglutamate absorption have been performed with compounds partly or completely purified from yeast. Retief (1969) has shown that there may be wide variations in the availability of pteroylpolyglutamates from different foods, for instance, that folate from calf's liver, peas, and spinach is better absorbed than equivalent amounts from tomato, cauliflower, and pumpkin. Earlier observations of Baumslag and Metz (1964) suggest that folate in lettuce is relatively well absorbed. Apart from differences due to variation in the chemical composition of the polyglutamates, differences may also arise because of other substances in the foods. Cellulose has been reported to impede folate absorption by complexing the vitamin in insoluble form (Luther, Santini, Brewster, PerezSantiago, and Butterworth, 1965). There may also be 'folate conjugase inhibitors' in food and this point is discussed next.

\section{PTEROYLPOLYGLUTAMATE HYDROLASE}

The enzyme responsible for the hydrolysis of the glutamyl- $\gamma$-glutamyl peptide chain has been called 'folate conjugase' (Bird, Binkley, Blood, Emmett, and Pfiffner, 1945) but this is an unsatisfactory name since it suggests the opposite effect to the 'deconjugation' that the enzyme carries out. The alternative names 'pteroylpolyglutamate hydrolase' (PPH) (Hoffbrand and Peters, 1969) and 'gammaglutamylcarboxypeptidase' (Blakley, 1969; Bernstein, Gutstein, and Weiner, 1970a) are therefore used. The enzyme, which hydrolyses the peptide chain to the monoglutamate form, has not however, been purified, and it is possible that two or more enzymes are con- cerned, for instance, one that hydrolyses the higher polyglutamates to the triglutamate stage, and a second which takes the tri- to the monoglutamate form (Mims and Bird, 1950). Similar enzymes exist in nature, such as that in chick pancreas, but this differs from human PPH by such characteristics as $p \mathrm{H}$ optimum and by producing pteroyldiglutamate as an end-product.

There is no delay in the absorption of polyglutamate forms compared to pteroylglutamic acid, implying that the hydrolysis of dietary polyglutamates to monoglutamates occurs rapidly. The exact anatomical site of the hydrolysis is, however, uncertain. Small amounts of PPH are present in saliva, bile, pancreatic, and duodenal juices, but the $p \mathrm{H}$ optimum of the enzyme is low (between 4.0 and 5.0 ) and enzyme activity in the lumen of the upper small intestine from these sources and from sloughed intestinal cells is very low (Santini, Berger, Berdasco, Sheehy, Avites, and Daisla, 1962; Klipstein, 1967; Hoffbrand and Peters, 1970). Much higher concentrations of the enzyme are present in the jejunal mucosa, and this seems a more likely site of the hydrolysis, particularly, as deconjugation of pteroylpolyglutamates has been reported during transport across everted sacs of rat intestine in vitro (Rosenberg, Streiff, Godwin, and Castle, 1969) where the luminal enzyme is presumably absent. Moreover, absorption of pteroylpolyglutamates appears to be normal in adult pernicious anaemia (see Table V) when presumably the $p \mathrm{H}$ of the upper small intestine is particularly unfavourable for the action of the luminal enzyme.

Surprisingly, if the mucosal enzyme does have an absorptive function, it is not situated in the brush border of the mucosal cell, the usual subcellular site for an absorptive enzyme, but is concentrated in the mucosal cell lysosomes (Hoff brand and Peters, 1970). Furthermore, the concentration of the enzyme in jejunal and ileal mucosa in man is the same (Hoffbrand and Peters, 1970)-though Bernstein et al (1970b) report that in the guinea pig the jejunal concentration of the enzyme is higher than that of the ileum.

If polyglutamate hydrolysis does occur within the intestinal cells, the localization of the enzyme in lysosymes suggests that the compounds may be absorbed by a process of pinocytosis and are then digested in the secondary lysosomes formed by fusion of pinocytotic vacuoles with primary lysosomes containing the enzyme (Hoffbrand and Peters, 1970). Alternatively, it is possible that polyglutamates are transported to the lysosomes by some process other than pinocytosis though, in view of their relatively high molecular weight (greater than 800 ), they would not be expected to cross the lyso- 
somal membrane. The easy saturation of the absorptive process for pteroylpolyglutamates implies that entry of the compounds into the cells may be one of the limiting factors in their absorption, the location of the enzyme inside the mucosal cell and the large amounts present there making it less likely that hydrolysis within the mucosal cell could be a limiting factor.

If, on the other hand, deconjugation takes place only in the small intestinal lumen, then this could well be a limiting factor in view of the small amounts of enzyme found there. Until more is known about the mechanism of entry of all folates into the jejunal cells, however, it is difficult to know which process is so easily saturated during polyglutamate absorption.

\section{Inhibitors of pteroylpolyglutamate hydrolase}

The enzyme is usually estimated by incubating non$L$. case $i$ active pteroylpolyglutamate substrate with the enzyme preparation and measuring the amount of free folate released in a given time. A more elegant technique using labelled pteroylpolyglutamates has also been described (Baugh and Krumdieck, 1969).

The presence of inhibitors of PPH in natural materials was originally suggested by Mims, Swendseid, and Bird (1947). They showed an apparent inhibition of enzyme activity by nucleic acids. Subsequent work has shown that DNA and RNA directly inhibit the growth of $L$. casei which was used to assess the enzyme activity and fail to confirm that these substances inhibit the enzyme itself (A. V. Hoffbrand, C. Griffin, and T. J. Peters, unpublished observations). Glutamic acid polypeptides linked to para-aminobenzoic acid have also been reported to inhibit chick pancreas PPH (Sims and Totter, 1947) while Bernstein et al (1970a and b) describe inhibition of human PPH by bile salts and by sulphobromophthalein. Anticonvulsant drugs and the contraceptive 'pill' have also been described as PPH inhibitors and these hypotheses are discussed further below.

\section{FURTHER EVENTS}

It is likely that partly or fully reduced pteroylmonoglutamates (whether ingested as such or derived by hydrolysis of partly or fully reduced pteroylpolyglutamates) are fully reduced and methylated within the jejunal mucosa before they enter portal blood (Chanarin and Perry, 1969; Perry and Chanarin, 1970). This conclusion is based on the finding of radioactive folate active for $L$. case $i$ and not for $S$. faecalis in the blood stream after oral ingestion of radioactive dihydrofolic and tetrahydrofolic acid but not after their intravenous administration. Whitehead, Pratt, Viallet, and Cooper (1970) have also shown that ingested 5-formyltetrahydrofolic acid (folinic acid, citrovorum factor) is also converted ${ }_{0}$ to 5-methyltetrahydrofolate during its transfer across $\frac{0}{5}$ the jejunal mucosa in man.

Two enzyme systems must be concerned in these $\vec{F}$ conversions: (1) dihydrofolate reductase (DHFR) which reduces dihydrofolate (and much less readily pteroylglutamic acid) to tetrahydrofolate; (2) at $\frac{\bar{c}}{\bar{s}}$ least two enzyme(s) concerned with methylation of $\frac{\rho}{\bar{\sigma}}$ tetrahydrofolate at the $\mathrm{N}_{5}$ position (eg, serine 2 hydroxymethyltransferase and 5,10-methylenetetrahydrofolate reductase).

Darzynkiewicz, Rogers, Barnard, Wong, and $\stackrel{\circ}{-}$ Werkheiser (1966) using autoradiographic techniques $\vec{\omega}$ localized DHFR to the apical position of the jejunal mucosal cells in the mouse. In our own studies, we have found the enzyme to be localized principally in the soluble (cell sap) fraction of the jejunal cells ir in the guinea-pig (Table II), so that if both decon- $-\overrightarrow{-}$ jugation and reduction do take place in the mucosalo cell they must take place in different parts (lyso-음 somes and cell cytoplasm) of the cell.

Protein $\left(\right.$ mollmg/hr) ${ }^{2}$

\begin{tabular}{lr}
\hline Whole homogenate & $88 \cdot 3$ \\
Brush borders and nuclei & $8 \cdot 2$ \\
Mitochondria and lysosomes & - \\
Microsomes & $17 \cdot 1$ \\
Cell sap & 101.5 \\
\hline
\end{tabular}

Table II Subcellular localization of dihydrofolate reductase in guinea-pig intestinal mucosa ${ }^{1}$

${ }^{1}$ Assay method of Bertino and Fischer (1964).

'Mean of four experiments.

\section{CONCLUSIONS}

Dietary pteroylpolyglutamates are hydrolysed to the pteroylmonoglutamate form, probably in the jejunal mucosa. If the compounds are already partly reduced, it is likely that they are fully reduced and methylated in the mucosa so that the major compound entering. portal blood after ingestion of a wide variety of dietary folate compounds is 5-methyltetrahydro- $₹$ pteroylmonoglutamate. Pteroylglutamic acid itself is윽 largely absorbed unchanged but whether this is by $>$ an active or passive process and whether partial reduction and methylation of pteroylglutamic acid also occurs is uncertain. In both animals and man, however, a saturable process is involved in transfer 0 of pteroylglutamic acid across the upper smallintestinal mucosa.

\section{Malabsorption of Folate}

The most usual cause of folate deficiency in the 0 western hemisphere is inadequate dietary intake of ${ }_{0}$ the vitamin. Many severely folate-deficient patients 
also suffer from a condition which accelerates folate depletion, eg, haemolytic anaemia or myelosclerosis; the most common factor precipitating folate deficiency throughout the world, however, is pregnancy. There are only three diseases in which malabsorption of folate is considered the major cause of the deficiency-tropical sprue, coeliac disease, and the extremely rare disease of specific malabsorption of folate (Table III). In a number of other conditions, malabsorption of folate may play a part, at least in some of the patients, in causing folate deficiency though in these conditions, inadequate intake and/or excess utilization of the vitamin are probably more important factors in patients with severe deficiency (Table IV). The conditions in which there is still dispute about whether folate malabsorption occurs at all, or where folate malabsorption has been reported in only one study of pteroylglutamic acid absorption are given in Tables $\mathrm{Va}$ and b.

\section{ESTABLISHED CAUSES OF MALABSORPTION OF} FOLATE

Tropical sprue and coeliac disease

Malabsorption of folate is now known to be a consistent feature of untreated tropical sprue and of untreated coeliac disease, both in children and adults. In these diseases there is structural and functional damage to the jejunal mucosa. Folate deficiency may be due not only to malabsorption of dietary folate but also to failure of absorption of biliary folate, and of folate from sloughed intestinal cells. Loss of folate from the latter source may well be excessive in these syndromes (Croft, Loehry, and Creamer, 1968). Reduced folate intake may also be a factor in many of the patients. Particularly in tropical sprue absorption of dietary folate appears to be more impaired than absorption of pteroyglutamic acid (Sheehy, Rubini, Perez-Santiago, Santini, and Haddock, 1961; Jeejeebhoy, Desai, Borkar, Deshpande, and Pathase, 1968; Hoffbrand, Necheles, Maldonado, Horta, and Santini, 1969; Klipstein, 1969), even though PPH concentrations in the succus entericus (Klipstein, 1967) and in the jejunal mucosa in both tropical sprue and coeliac disease (Hoffbrand et al, 1969; Hoffbrand, Douglas, Fry, and Stewart, 1970) are normal.

It has been proposed that the selective malabsorption of pteroylpolyglutamates in sprue is due to inhibition of jejunal PPH. No definite inhibitors have been identified in this disease, though a naturally occurring anti-folate compound (Butterworth, 1968) and a bacterial or viral inhibitor (Klipstein, 1968), have been proposed to have this action. More recently, Bernstein et al (1970b) have suggested that products of bile salt degradation by bacteria may be
Malabsorption usually the major cause of folate deficiency

Tropical sprue

Coeliac disease

Adult coeliac disease

Coeliac lesion associated with dermatitis herpetiformis

Specific malabsorption of folate

Malabsorption usually a minor cause of folate deficiency

Jejunal resection (extensive)

Crohn's disease

Partial gastrectomy

Table III Conditions in which malabsorption of folate has been established

Disputed conditions in which malabsorption may occur

Intestinal stagnant-loop syndrome

Anticonvulsant drug therapy

Contraceptive 'pill' therapy

Folate deficiency

Conditions in which single reports suggest malabsorption of folate may occur

Congestive heart failure

Alcoholism

Chronic lymphocytic leukaemia, lymphoma

Table IV Conditions in which malabsorption of folate may occur

\begin{tabular}{lllll}
\hline & Number & Range & Mean & Significance \\
\hline $\begin{array}{l}\text { Controls } \\
\begin{array}{c}\text { Treated pernicious } \\
\text { anaemia }\end{array}\end{array}$ & 25 & $3.0-16.6$ & 8.0 & \\
\hline
\end{tabular}

Table Va Serum folate levels $(\mathrm{ng} / \mathrm{ml})$ in control subjects and in patients with pernicious anaemia receiving maintenance vitamin $B_{12}$ therapy for at least one year ${ }^{1}$ Four $(15 \%)$ patients had serum folate levels less than $3.0 \mathrm{ng} / \mathrm{ml}$.

\begin{tabular}{|c|c|c|c|}
\hline Patient & $\begin{array}{l}\text { Fasting } \\
\text { Serum } \\
\text { Folate } \\
(\mathrm{ng} / \mathrm{ml})\end{array}$ & $\begin{array}{l}\text { Peak Rise after } \\
200 \mathrm{\mu g} \text { Pteroyl- } \\
\text { glutamic Acid } \\
(\mathrm{ng} / \mathrm{ml})\end{array}$ & $\begin{array}{l}\text { Peak Rise after } \\
\text { Equivalent Dose of } \\
\text { Pteroylpolyglutamates } \\
(\text { ng/ml })\end{array}$ \\
\hline $\begin{array}{l}1 \\
2 \\
3 \\
4 \\
5 \\
\text { Lower } 1\end{array}$ & $\begin{array}{r}4 \cdot 1 \\
4 \cdot 0 \\
18 \cdot 0 \\
10 \cdot 0 \\
6 \cdot 2 \\
\text { it in }\end{array}$ & $\begin{array}{l}13 \cdot 3 \\
11 \cdot 7 \\
\frac{12}{12} \cdot 1 \\
15 \cdot 4\end{array}$ & \begin{tabular}{r|}
$10 \cdot 3$ \\
$11 \cdot 4$ \\
$16 \cdot 0$ \\
$9 \cdot 8$ \\
$12 \cdot 3$
\end{tabular} \\
\hline \multicolumn{2}{|c|}{$\begin{array}{l}\text { Lower limit in } \\
\text { normal subjects }\end{array}$} & 7.5 & $7 \cdot 4$ \\
\hline
\end{tabular}

Table $\mathrm{Vb}$ Peak rise in serum folate level in five adult patients with treated pernicious anaemia following an oral dose of $200 \mu \mathrm{g}(0.45 \mu$ mole $)$ pteroylglutamic acid and $200 \mu \mathrm{g}(0.45 \mu$ mole, folate equivalent $)$ of $a$ semi-purified preparation of pteroylpolyglutamates prepared from yeast 
PPH inhibitors but this seems unlikely since, as mentioned below, the predominant effect of small intestinal bacteria is to raise serum folate, not to cause folate deficiency.

Sufficient folate may be absorbed from a small (25-200 $\mu \mathrm{g})$ dose of pteroylglutamic acid to produce a haematological response in some patients with tropical sprue (Sheehy et al, 1961) and coeliac disease with megaloblastic anaemia (Mollin and Waters, 1968). Indeed, up to $70 \%$ of a $200 \mu \mathrm{g}$ oral dose of pteroylglutamic acid may be absorbed in untreated coeliac disease (Kremenchuzky et al, 1967). Sufficient folate can usually be absorbed from large doses of pteroylglutamic acid (5 mg or more) to cause a satisfactory haematological response and to saturate body folate stores in patients with either tropical sprue or coeliac disease. Baker, Frank, Ziffer, and Feingold (1968), however, have made the remarkable, and as yet unconfirmed, observation that severe malabsorption of pteroylglutamic acid occurs in tropical sprue and adult coeliac disease which can be corrected by feeding the pteroylglutamic acid with lyophilized calf jejunum. Apparently the postulated factor in calf jejunum which enhances absorption of pteroylglutamic acid in these diseases was not a protein since it could not be destroyed by autoclaving the calf jejunum preparation. These remarkable findings remain totally unexplained.

\section{Dermatitis herpetiformis}

Patients with this skin disease may show a jejunal mucosal lesion resembling that of coeliac disease and in a proportion of patients the jejunal abnormality responds to a gluten-free diet. Absorption of pteroylglutamic acid is usually normal but nevertheless the patients show folate deficiency and malabsorption of pteroylpolyglutamates (Hoffbrand et al, 1970).

\section{Jejunal resection}

Malabsorption of pteroylglutamic acid and of dietary folate occurs if the jejunum is resected (Chanarin and Bennett, 1962; Baker, Thomson, and Feingold, 1969). Pavesio (1965) studied 30 children and found a slightly reduced absorption of pteroylglutamic acid in six patients with an ileal resection but marked reduction in nine patients with a jejunal resection. Sufficient absorption usually occurs from the remaining portion of the small intestine after jejunal resection, however, to protect patients from severe folate deficiency unless reduced intake of folate occurs.

\section{Crohn's disease}

Folate deficiency occurs frequently in patients with active Crohn's disease. A number of factors are involved - poor diet, excess utilization of the vitamin, 7 and probably malabsorption in some patients. This $\frac{*}{5}$ is probably partly due to involvement of the jejunum $\underline{\underline{C}}$ by the disease but may also be due to impaired $\overrightarrow{\vec{F}}$ function of the small intestine not actually involved $\stackrel{\vec{P}}{+}$ by the disease (Hoffbrand, Stewart, Booth, and $\frac{\mathrm{C}}{\mathrm{C}}$ Mollin, 1968).

\section{Partial gastrectomy}

Mild folate deficiency occurs frequently in post- \% gastrectomy patients; when megaloblastic anaemia $\vec{\circ}$ due to the deficiency occurs, however, the predominant factor is always poor diet. A minor degree of $\vec{\omega}$ malabsorption of pteroylglutamic acid and of dietary folate has been reported in a proportion of the 8

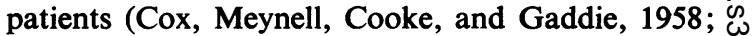
Hoff brand, Hines, Harrison, and Mollin, 1967; í Markkanen, 1968; Chanarin, 1969). The cause of $\overrightarrow{.}$ this may be excessively rapid passage of the vitamin 8 from the gastric remnant to the lower jejunum, and $\frac{}{5}$ possibly alterations in $p H$ in the upper jejunum. Severe malabsorption of folate after partial gastrectomy may be due to occult coeliac disease.

\section{Specific malabsorption of folate}

This disease has been reported in two children (Luhby et al, 1961; Luhby and Cooperman, 196 and one girl of 18 (Lanzkowsky et al, 1969; Lanz kowsky, 1970). The patients showed relapsing megaloblastic anaemia requiring therapy with large (10 $\mathrm{mg}$ or more) doses of pteroylglutamic acid by mouth, mental retardation and epileptic convulsions, and other neurological features, eg, ataxia or choreoathetotic movements. Absorption of all forms of folate tested was impaired, including absorption of pteroylglutamic acid, 5-methyltetrahydrofolate, and of pteroylpolyglutamates. Thus, lack of enzymes for deconjugation, reduction, or methylation could not be the explanation. The patient of Lanzkowsky responded well to a small parenteral dose of pteroylglutamic acid.

It is of interest that the patient of Lanzkowsky was also shown to have defective transport of folate into the cerebrospinal fluid and this may account for the neurological disturbances. It also suggests that folate absorption and folate transport into the cerebro- $\tilde{N}$ spinal fluid may occur by related processes, and, since cerebrospinal fluid folate is normally three times that of plasma (Herbert and Zalusky, 1961), this is indirect evidence that both processes may be active.

POSSIBLE CAUSE OF MALABSORPTION OF FOLATE $\stackrel{\mathscr{\oplus}}{\rightarrow}$ In these conditions (Table IV) malabsorption of $\square$ folate has been described but is not yet established as a significant cause of folate deficiency. 
Intestinal blind-loop syndrome

Malabsorption of pteroylglutamic acid has been reported in a few patients with this syndrome (Cooke, Cox, Fone, Meynell, and Gaddie, 1963; Barrett and Holt, 1967; Wakisaka, 1968). These workers postulated that colonic bacteria in the upper jejunum might render folate unavailable for absorption. Hoffbrand, Tabaqchali, Booth, and Mollin (1971) have demonstrated lactobacilli capable of consuming folate in the small intestine of a patient with this syndrome. The predominant effect of an abnormal upper intestinal flora in the stagnant-loop syndrome, however, is to raise serum folate by producing folate that is absorbed (Hoffbrand, Tabaqchali, and Mollin, 1966; Klipstein and Lipton, 1970; Hoffbrand et al, 1971). Even though exceptional patients with large numbers of faecal organisms in the jejunum show folate deficiency and malabsorption of pteroylglutamic acid, there is as yet no conclusive evidence that the deficiency in these particular patients is due to malabsorption of dietary folate rather than to inadequate dietary intake of the vitamin (Hoffbrand et al, 1971).

\section{Anticonvulsant drug therapy}

Folate deficiency occurs frequently in patients receiving the anticonvulsant drugs, diphenylhydantoin (phenytoin) and primidone. A number of theories have been proposed to explain this deficiency. (1) Inhibition of enzymes concerned with folate metabolism but no such inhibition has been convincingly demonstrated. (2) Displacement of folate from its transport protein (Klipstein, 1964)but cell uptake of folate is not affected by phenytoin in plasma (Das and Hoffbrand, 1970; Corcino, Waxman, and Herbert, 1971). (3) Induction of an enzyme concerned with folate metabolism causing excess folate utilization (Richens and Waters, 1971); this is unlikely since barbiturates are much more powerful enzyme inducers than phenytoin or primidone yet the latter two drugs are much more likely to cause folate deficiency. (4) Inhibition of PPH causing selective malabsorption of pteroylpolyglutamates (Hoffbrand and Necheles, 1968; Rosenberg, Godwin, Streiff, and Castle, 1968); other workers (Baugh and Krumdieck, 1969; Bernstein et $a l, 1970$ b) have not confirmed this. (5) Malabsorption of pteroylglutamic acid; this has been reported in the rat (Hepner, 1969) and in humans (Meynell, 1966; Dahlke and Mertens-Roesler, 1967). Hepner, Gerson, Hepner, Brown, Cohen, Herbert, and Janowitz (1970) suggested that the drugs do this by inhibiting intestinal Na-K ATPase. Aledort, Gerson, Cohen, Herbert, and Janowitz(1970)and Benn,Swan, Cooke, Blair, Matty, and Smith,(1971) have produced evidence for an alternative mechanism for phenytoin- induced malabsorption of pteroyl-glutamic acid. They demonstrated higher $p \mathrm{H}$ values in the upper small intestine of three patients on long-term anticonvulsant therapy who had developed folatedeficient megaloblastic anaemia than in control subjects. They also found that feeding either phenytoin or sodium bicarbonate with pteroylglutamic acid caused 'flat' absorption curves for the vitamin in normal volunteers. On the basis of these findings, they conclude that phenytoin causes malabsorption of pteroylglutamic acid by raising the $p \mathrm{H}$ in the lumen of the duodenum and jejunum above the optimum for pteroylglutamic acid absorption. Elsborg (1970) has indeed shown (in the rat) that phenytoin only causes malabsorption of pteroylglutamic acid if it raises the $p \mathrm{H}$ of the luminal contents, the drug being highly alkaline in solution, and as mentioned earlier, pteroylglutamic acid absorption is $p \mathrm{H}$ dependent with an optimum, at least in the rat, around $p \mathrm{H} 6 \cdot 0$.

It is necessary, however, to establish that the flat plasma curves after feeding pteroylglutamic acid with phenytoin reflect true malabsorption of pteroylglutamic acid rather than simply delayed absorption since other workers have found normal absorption of pteroylglutamic acid in drug-treated epileptics. Moreover, if alkalinization of the upper small intestine does cause serious malabsorption of folate, it is surprising that in pernicious anaemia, a condition in which the upper small intestine may well be more alkaline than normal due to gastric achlorhydria, the mean serum folate level in the treated state is not significantly different from that of a control group and folate absorption is normal (Table V).

\section{Contraceptive pill therapy}

Some workers (Shojania, Hornady, and Barnes, 1968 and 1969), though not all (Spray, 1968; McLean, Heine, Held, and Streiff, 1968), have found low serum folate levels in women taking the 'pill'. Streiff (1970) reports that oral contraceptives cause selective malabsorption of pteroylpolyglutamates by inhibiting intestinal PPH (Streiff and Green, 1970). In view of the findings of McLean, Heine, Held, and Streiff (1970) of similar absorption of pteroylglutamic acid and pteroylpolyglutamates in pregnancy, these findings in patients receiving the synthetic oestrogens and progesterones are difficult to understand, and require confirmation. Coeliac disease was not excluded by jejunal biopsy as the cause of malabsorption in Streiff's folate-deficient cases, nor in two similar cases reported by Necheles and Snyder (1970).

Folate deficiency

The relation between folate deficiency and folate 
absorption is complex. It is well known that folate therapy improves the structure and absorptive function of the small intestine in tropical sprue and improvement in intestinal absorption of xylose and vitamin $B_{12}$ has also been reported in anticonvulsant megaloblastic anaemia (Reynolds, Hallpike, Phillips, and Matthews, 1965). On the other hand, in nutritional folate deficiency jejunal structure has been reported both as normal (Winawer, Sullivan, Herbert, and Zamcheck, 1965) and megaloblastic (Bianchi, Chipman, Dreskin, and Rosensweig, 1970). Absorption of xylose and glucose is usually normal though malabsorption of vitamin $B_{12}$ occurs frequently, suggesting that ileal absorptive function is impaired. Tests of folate absorption are difficult to perform in the folate-deficient state since all tests of folate absorption except measurement of the faecal excretion of labelled folates require presaturation of the body with folate and this will of necessity correct folate deficiency of intestinal cells. It is likely, however, that folate deficiency contributes to malabsorption of folate in humans at least with tropical sprue and that the absorption of folate in these patients, like that of other nutrients, improves with folate therapy. It is also probable that folate $a b-$ sorption is reduced in other situations where the small bowel suffers general nonspecific damage as in kwashiorkor and starvation.

In each of the remaining conditions, only one group has reported patients showing malabsorption of pteroylglutamic acid.

\section{Alcohol}

A number of mechanisms are responsible for folate deficiency in alcoholics-poor nutrition, liver damage, and possibly inhibition of folate coenzymes. Halsted, Griggs, and Harris (1967) reported flat plasma curves after feeding ${ }^{3} \mathrm{H}$-pteroylglutamic acid in some chronic alcoholics. Total urinary excretion of radioactivity was normal, however, so absorption may well have been delayed rather than impaired.

\section{Congestive heart failure}

This is a recently recognized cause of folate deficiency (Hyde and Loehry, 1968; Brody, Soltys, and Zinsser, $1969)$ and the major factor is probably excess urinary folate excretion (Retief and Huskisson, 1969). Hyde and Loehry (1968) reported malabsorption of pteroylglutamic acid in seven of 25 patients tested, malabsorption being most frequent in those with long-standing heart failure.

Lymphosarcoma and chronic lymphocytic leukaemia Pitney, Joske, and MacKinnon (1960) found reduced absorption of pteroylglutamic acid in eight of $\mathbf{1 0}$ patients with a lymphoma and five of eight with chronic lymphocytic leukaemia. They considered that 0 these abnormalities were largely due to involvement $\stackrel{0}{+}$ of the small intestine by the disease since other tests of intestinal absorption were abnormal in most of the patients.

It is a pleasure to thank Dr T. J. Peters for invaluable $\frac{\bar{D}}{\bar{D}}$ cooperation and helpful discussions during much of $\frac{\bar{\rho}}{\bar{D}}$ this work, and for advice in preparing this manu- $\mathbb{Q}$ script. I am also extremely grateful to Mrs C. Griffin, ®ొ Miss A. Quinlan, and Mr J. O. Morgan for invaluable $\vec{\circ}$ technical assistance throughout.

References

Anderson, B., Belcher, E. H., Chanarin, I., and Mollin, D. L. (1960). The urinary and faecal excretion of radioactivity after oral doses is of ${ }^{2} \mathrm{H}$-folic acid. Brit. J. Haemat., 6, 439-455.

Baker, H., Frank, O., Feingold, S., Ziffer, H., Gellene, R. A., Leevy, ơ C. M., and Sobotka, H. (1965). The fate of orally and parenterally administered folates. Amer.J. clin. Nutr., 17, 88-95.

Baker, H., Frank, O., and Sobotka, H. (1964). Mechanisms of folic o acid deficiency in nontropical sprue. J. Amer. med. Ass., 187, 윽 119-121.

Baker, H., Frank, O., Ziffer, H., and Feingold, S. (1968). Reversal of $-\overrightarrow{ }$ folate malabsorption in tropical and non-tropical sprue by calf $\frac{\mathcal{\Omega}}{C}$ jejunum. Brit. med. J., 3, 472-474.

Baker, H., Thomson, A. D., and Feingold, S. (1969). Role of the jejunum in the absorption of folic acid and its polyglutamates. Amer. J. clin. Nutr., 22, 124-132.

Baker, S. J., Kumar, S., and Swaminathan, S. P. (1965). Excretion of $\overrightarrow{0}$ folic acid in bile. Lancet, 1,685 .

Barrett, C. R., and Holt, P. R. (1967). Postgastrectomy blind-loq syndrome. Megaloblastic anaemia secondary to malabsorption of folic acid. Amer. J. Med., 41, 629-637.

Baugh, C. M., and Krumdieck, C. L. (1969). Effect of phenytoin o folic acid conjugases. Lancet. 2, 519-521.

Baumslag, N., and Metz, J. (1964). Response to lettuce in patients with megaloblastic anaemia associated with pregnancy. $S$. Afr. med. J., 38, 611-613.

Benn, A., Swan, C. H. J., Cooke, W. T., Blair, J. A., Matty, A. J., and Smith, M. E. (1971). Effect of intraluminal $p H$ on the $\overline{\bar{O}}$ absorption of pteroylglutamic acid. Brit. med. J., 1, 148-150.

Bernstein, L. H., Gutstein, S., and Weiner, S. (1970a). Gamma glutamyl carboxypeptidase (conjugase), the folic acid-releasing enzyme of intestinal mucosa. Amer. J. clin. Nutr., 23, 919-925.

Bernstein, L. H., Gutstein, S., Weiner, S., and Efron, G. (1970b). The absorption and malabsorption of folic acid and its poly- $\bar{O}$ glutamates. Amer. J. Med., 48, 570-579.

Bertino, J. R., and Fischer, G. A. (1964). Techniques for the study of resistance folic acid antagonists. Meth. med. Res., 10, 297-307.

Bianchi, A., Chipman, D. W., Dreskin, A., and Rosensweig, N. S. (1970). Nutritional folate deficiency with megaloblastic changes in small bowel epithelium. New Engl. J. Med., 282, 859-861.

Bird, O. D., Binkley, S. B., Blood, E. S., Emmett, A. D., and Pfiffner, J. J. (1945). On the enzymic formation of vitamin B, from its conjugate. J. biol. Chem., 157, 413-414.

Blakley, R. L. (1969). Folic acid and related pteridines. North Holland Research Monographs. Frontiers of Biology, Vol. 13.

Brody, J. I., Soltys, H. D., and Zinzzer, H. F. (1969). Folic acid $N$ deficiency in congestive heart failure. Brit. Heart J., 31, 741-745. S

Burgen, A. S. V., and Goldberg, N. J. (1962). Absorption of folic acid N from the small intestine of the rat. Brit. J. Pharmacol., 19, 313-320.

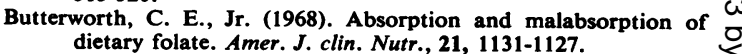

Butterworth, C. E., Jr., Baugh, C. M., and Krumdieck, C. (1969). A study of folate absorption and metabolism in man utilizing carbon-14-labelled polyglutamates synthesized by the solid phase method. J. clin. Invest., 48, 1131-1142.

Butterworth, C. E., Jr., Nadel, H., Perez-Santiago, E., Santini, R., and Gardner, F. H. (1957). Folic acid absorption, excretion and leucocyte concentration in tropical sprue. J. Lab. clin. Med., 50, 673-681. 
Butterworth, C. E., Jr., Santini, R., Jr., and Frommeyer, W. B., Jr. (1963). The pteroylglutamate components of American diets as determined by chromatographic fractionation. J. clin. Invest., 42, 1929-1939.

Chanarin, I. (1969). The Megaloblastic Anaemias. Blackwell, Oxford.

Chanarin, I., Anderson, B. B., and Mollin, D. L. (1958). The absorption of folic acid. Brit. J. Haemat., 4, 156-166.

Chanarin, I., and Bennett, M. C. (1962). Absorption of folic acid and Dxylose as tests of small intestinal function. Brit. med. J., 1, 985-989.

Chanarin, I., and Perry, J. (1969). Evidence for reduction and methylation of folate in the intestine during normal absorption. Lancet, 2, 776-778.

Chanarin, I., Rothman, D., Perry, J., and Stratfull, D. (1968). Normal dietary folate, iron and protein intake with special reference to pregnancy. Brit. med.J., 2, 394-397.

Cohen, N. (1965). Differential microbiological assay in study of folic acid absorption in vitro by everted intestinal sacs. Clin. Res., 13, 252.

Cooke, W. T., Cox, E. V., Fone, D. J., Meynell, M. J., and Gaddie, R. (1963). The clinical and metabolic significance of jejunal diverticulosis. Gut, 4, 115-135.

Copperman, J. M., and Luhby, A. L. (1965). The physiological fate in man of some naturally occurring polyglutamates of folic acid. Israel J. med. Sci., 1, 704-707.

Corcino, J. J., Waxman, S., and Herbert, V. (1971). Uptake of tritiated pteroylglutamic acid ( ${ }^{3} \mathrm{H}-\mathrm{PGA}$ ) by human marrow cells in vitro. Brit.J. Haemat., 20, 503-509.

Cox, E. V., Meynell, M. J., Cooke, W. T., and Gaddie, R. (1958). The folic acid excretion test in the steatorrhoea syndrome. Gastroenterology, 35, 390-397.

Croft, D. N., Loehry, C. A., and Creamer, B. (1968). Small-bowel cell-loss and weight-loss in the coeliac syndrome. Lancet, 2 , 68-70.

Dahlke, M. B., and Mertens-Roesler, E. (1967). Malabsorption of folic acid due to diphenylhydantoin. Blood, 30, 341-351.

Darzynkiewicz, Z., Rogers, A. W., Barnard, E. A., Wong, D. H., and Werkheiser, W. C. (1966). Autoradiography with tritiated methotrexate and the cellular distribution of folate reductase. Science, 151, 1528-1530.

Das, K. C., and Hoff brand, A. V. (1970). Studies of folate uptake by phytohaemagglutinin-stimulated lymphocytes. Brit.J. Haemat., $19,203-221$.

Denko, C. W. (1951). Pteroylglutamic acid clearance in normal adults. J. appl. Physiol., 3, 559-562.

Denko, C. W., Grundy, W. E., Wheeler, N. C., Henderson, C. R., Berryman, G. H., Friedemann, T. E., and Youmans, J. B. (1946). The excretion of B-complex vitamins by normal adults on a restricted intake. Arch. Biochem., 11, 109-117.

Elsborg, L. (1970). Inhibition of intestinal absorption of folic acid as a possible pathogenesis in anticonvulsant megaloblastic anaemia. In Proceedings XIIIth International Congress of Haematology, Munich, p. 378.

Gerson, C. D., Hepner, G. W., Brown, N., Cohen, N., Herbert, V., and Janowitz, H. D. (1970). Inhibition by diphenylhydantoin (Dilantin) of folic acid absorption in man. J. clin. Invest., 49, 33a.

Girwood, R. H. (1953). A folic-acid excretion test in the investigation of intestinal malabsorption. Lancet, 2, 53-60.

Godwin, H. A., and Rosenberg, I. H. (1970). Absorption of synthetic 'cold' and Tritium-labelled pteroylheptaglu tamic acid. J. clin. Invest., 49, 35a.

Halsted, C. H., Griggs, R. C., and Harris, J. W. (1967). The effect of alcoholism on the absorption of folic acid ( ${ }^{3} \mathrm{H}-\mathrm{PGA}$ ) evaluated by plasma levels and urinary excretion. J. Lab. clin. Med., 69, 116-131.

Hepner, G. W. (1969). The absorption of pteroylglutamic (folic) acid in rats. Brit. J. Haemat., 16, 241-249.

Hepner, G. W., Aledort, L. M., Gerson, C. D., Cohen, N., Herbert, V., and Janowitz, H. D. (1970). Inhibition of intestinal ATPase by diphenylhydantoin and acetazolamide. Clin. Res., 18, 382.

Hepner, G. W., Booth, C. C., Cowan, J., Hoffbrand, A. V., and Mollin, D. L. (1968). Absorption of crystalline folic acid in man. Lancet, 2, 302-306.

Herbert, V. (1967). Biochemical and hematologic lesions in folic acid deficiency. Amer. J. clin. Nutr., 20, 562-569.

Herbert, V. (ed.) (1970). Symposium on vitamin $B_{12}$ and folate. Amer. J. Med., 48, 539-540.
Herbert, V., and Shapiro, S. S. (1962). The site of absorption of folic acid in the rat in vitro. Fed. Proc., 21, 260-000.

Herbert, V., and Zalusky, R. (1961). Selective concentration of folic acid acitivity in cerebro-spinal fluid. Fed. Proc., 20, 453.

Hoffbrand, A. V. (1969). Polyglutamyl forms of folic acid in man. Brit. med. J., 1, 51.

Hoff brand, A. V., Douglas, A. P., Fry, L., and Stewart, J. S. (1970). Malabsorption of dietary folate (pteroylpolyglutamates) in adult coeliac disease and dermatitis herpetiformis. Brit. med.J., 4, 85-89.

Hoffbrand, A. V., Hines, J. D., Harrison, R., and Mollin, D. L. (1967). In Post-Gastrectomy Nutrition, a Glaxo Symposium, edited by D. M. Krikler. Lloyd-Luke, London.

Hoff brand, A. V., and Necheles, T. F. (1968). Mechanism of folate deficiency in patients receiving phenytoin. Lancet, 2, 528-530.

Hoff brand, A. V., Necheles, T. F., Maldonado, N., Horta, E., and Santini, R. (1969). Malabsorption of folate polyglutamates in tropical sprue. Brit. med. J., 2, 543-547.

Hoff brand, A. V., and Peters, T. J. (1969). The subcellular localization of pteroylpolyglutamate hydrolase and folate in guinea-pig intestinal mucosa. Biochim. biophys. Acta (Amst.), 192, 479-485.

Hoff brand, A. V., and Peters, T. J. (1970). Recent advances in clinical and biochemical aspects of folate. Schweiz. med. Wschr., 100, 1954-1960.

Hoff brand, A. V., Stewart, J. S., Booth, C. C., and Mollin, D. L. (1968). Folate deficiency in Crohn's disease: Incidence, pathogenesis, and treatment. Brit. med.J., 2, 71-75.

Hoffbrand, A. V., Tabaqchali, S., Booth, C. C., and Mollin, D. L. (1971). Small intestinal bacterial flora and folate status in gastrointestinal disease. Gut. (In press.)

Hoff brand, A. V., Tabaqchali, S., and Mollin, D. L. (1966). High serum folate levels in intestinal blind-loop syndrome. Lancet, 1, 1339-1342.

Hurdle, A. D. F., Barton, D., and Searles, I. H. (1968). A method for measuring folate in food and its application to a hospital diet. Amer. J. clin. Nutr., 21, 1202-1207.

Hyde, R. D., and Loehry, C. A. E. H. (1968). Folic acid malabsorption in cardiac failure. Gut, 2, 717-721.

Jeejeebhoy, K. N., Desai, H. G., Borkar, A. V., Deshpande, V., and Pathase, S. M. (1968). Tropical malabsorption syndrome in West Indians. Amer. J. clin. Nutr., 21, 994-1006.

Kinnear, D. G., Johns, D. G., MacIntosh, P. C., Burgen, A. S. V., and Cameron, D. G. (1963). Intestinal absorption of tritiumlabeled folic acid in idiopathic steatorrhoea. Effect of a glutenfree diet. Canad. med. Ass. J., 89, 975-979.

Klipstein, F. A. (1963). Urinary excretion of orally administered tritium-labeled folic acid as a test of folic acid absorption. Blood, 21, 626-639.

Klipstein, F. A. (1964). Subnormal serum folate and macrocytosis associated with anticonvulsant drug therapy. Blood, 23, 68-86.

Klipstein, F. A. (1967). Intestinal folate conjugase activity in tropical sprue. Amer. J. clin. Nutr., 20, 1004-1009.

Klipstein, F. A. (1968). Tropical sprue. Gastroenterology, 54, 275-293.

Klipstein, F. A. (1969). Absorption of physiologic doses of folic acid in subjects with tropical sprue responding to tetracycline therapy. Blood, 34, 191-203.

Klipstein, F. A., and Lipton, S. D. (1970). Intestinal flora of folatedeficient mice. Amer. J. clin. Nutr., 23, 132-140.

Kremenchuzky, S., Musso, A. M., Hoffbrand, A. V., and Rochna Viola, E. M. (1967). Triated folic acid ( ${ }^{3} \mathrm{H}$ FA). Excretion tests for the study of folic acid absorption. J. nucl. Biol. Med., 2, 89-95.

Lanzkowsky, P. (1970). Congenital malabsorption of folate. Amer. J. Med., 48, 580-583.

Lanzkowsky, P., Erlandson, M. E., and Bezan, A. I. (1969). Isolated defect of folic acid absorption associated with mental retardation and cerebral calcification. Blood, 34, 452-465.

Luhby, A. L., and Cooperman, J. M. (1967). Quoted by Lanzkowsky (1970).

Luhby, A. L., Eagle, F. J., Roth, E., and Cooperman, J. M. (1961). Relapsing megaloblastic anaemia in an infant due to a specific defect in gastrointestinal absorption of folic acid. Amer.J. Dis. Child., 102, 482-483.

Luther, L., Santini, R., Brewster, C., Perez-Santiago, E., and Butterworth, C. E. (1965). Folate binding by insoluble components of American and Puerto Rican diets. Ala. J. med. Sci., 3, 389-393.

McLean, F. W., Heine, M. W., Held, B., and Streiff, R. R. (1969). Relationship between oral contraceptives and folic acid 
metabolism. Serum folic concentrations. Amer. J. Obstet. Gynec., 104, 745-747.

McLean, F. W., Heine, M. W., Held, B., and Streiff, R. R. (1970). Folic acid absorption in pregnancy: comparison of the pteroylpolyglutamate and pteroylmonoglutamate. Blood, 36, 628-631.

Markkanen, T. (1968). Absorption tests with natural folate material in controls and in gastrectemized patients. Amer. J. clin. Nutr., 21, 473-481.

Meynell, M. J. (1966). Megaloblastic anaemia in anticonvulsant therapy. Lancet, 1, 487.

Mims, V., and Bird, O. D. (1950). Proteolytic Enzymes. Quoted by Laskowski, M. (1950), Ann, Rev. Biochem. 19, 21-42.

Mims, V., Swendseid, M. E., and Bird, O. D. (1947). The inhibition of pteroylglutamic acid conjugase and its reversal. The effect of nucleic acid- and sulf hydryl-combining reagents. J. biol. Chem., 170, 367-377.

Mitchell, H. K., Snell, E. E., and Williams, R. J. (1941). The concentration of folic acid. J. Amer. chem. Soc., 63, 2284.

Mollin, D. L., and Waters, A. H. (1968). Nutritional megaloblastic anaemia. Symp. Swed. Nutr. Foundat., 6, 121-134.

Necheles, T. F., and Snyder, L. M. (1970). Malabsorption of folate polyglutamates associated with oral contraceptive therapy. New Engl. J. Med., 282, 858-859.

Paterson, D. E., David, R., and Baker, S. J. (1965). Radiodiagnostic problems in malabsorption. Brit. J. Radiol., 38, 181-191.

Pavesio, D. (1965). Folic acid adsorption test in various infantile intestinal diseases. Minerva pediat., 17, 1488-1491.

Perry, J., and Chanarin, I. (1968). Absorption and utilisation of polyglutamyl forms of folate in man. Brit. med. J., 4, 546-549.

Perry, J., and Chanarin, I. (1970). Intestinal absorption of reduced folate compounds in man. Brit. J. Haemat., 18, 329-339.

Pitney, W. R., Joske, R. A., and MacKinnon, N. L. (1960). Folic acid and other absorption tests in lymphosarcoma, chronic lymphocytic leukaemia, and some related conditions. J. clin. Path., 13, 440-447.

Prat t, R. F., and Cooper, B. A. (1971). Folates in plasma and bile of man after feeding folic acid- ${ }^{3} \mathrm{H}$ and 5 -formyltetrahydrofolate (folinic acid). J. clin. Invest., 50, 455-462.

Retief, F. P. (1969). Urinary folate excretion after ingestion of pteroylmonoglutamic acid and food folate. Amer.J. clin. Nutr., 22, 352-355.

Retief, F. P., and Huskisson, Y. J. (1969). Serum and urinary folate in liver disease. Brit. med. J., 2, 150-153.

Reynolds, E. H., Hallpike, J. F., Phillips, B. M., and Matthews, D. M. (1965). Reversible absorptive defects in anticonvulsant megaloblastic anaemia. J. clin. Path., 18, 593-598.

Richens, A., and Waters, A. H. (1971). Acute effect on phenytoin on serum folate concentration. Brit. J. Pharmacol. (In press.)

Rosenberg, I. H., and Godwin, H. A. (1971). The digestion and absorption of dietary folate. Gastroenterology, 60, 445-463

Rosenberg, I. H., Godwin, H. A., Streiff, R. R., and Castle, W. B. (1968). Impairment of intestinal deconjugation of dietary folate: a possible explanation of the megaloblastic anaemia associated with phenytoin therapy. Lancet, 2, 530-532.

Rosenberg, I. H., Streiff, R. R., Godwin, H. A., and Castle, W. B. (1969). Absorption of polyglutamic folate: Participation of deconjugating enzymes of the intestinal mucosa. New Engl. J. Med., 280, 985-993.

Santini, R., Berger, F. M., Berdasco, G., Sheehy, T. W., Avites, J., and Daisla, I. (1962). Folic asid activity in Puerto Rican foods. J. Amer. diet. Ass., 14, 562-567.
Sheehy, T. W., Rubini, M. E., Perez-Santiago, E., Santini, R., Jr., and Haddock, J. (1961). The effect of 'minute' and 'tritrated' amounts of folic acid on the megaloblastic anaemia of tropical sprue. Blood, 18, 623-636.

Shojania, A. M., Hornady, G., and Barnes, P. H. (1968). Oral contraceptives and serum-folate levels. Lancet, 1, 1376-1377.

Shojania, A. M., Hornady, G., and Barnes, P. H. (1969). Oral contraceptives and folate metabolism. Lancet, 1, 886.

Sims, E. S., and Totter, J. R. (1947). The inhibition of conjugase by a polypeptide of p-aminobenzoic acid. (Abstr.), Fed. Proc., 6, 291.

Smith, M. E., Matty, A. J., and Blair, J. A. (1970). The transport of pteroylglutamic acid across the small intestine of the rat. Biochim. biophys. Acta (Amst.), 219, 37-46.

Spencer, R. P., and Bow, T. M. (1964). In vitro transport of radiolabeled vitamins by the small intestine. J. nucl. Med., 5, 251-258.

Spray, G. H. (1952). The utilisation of folic acid from natural sources. Clin. Sci., 11, 425-428.

Spray, G. H. (1968). Oral contraceptives and serum-folate levels. Lancet, 2, 110-111.

Spray, G. H., and Witts, L. J. (1952). The utilisation of folic acid given by mouth. Clin. Sci., 11, 273-281.

Streiff, R. R. (1970). Folate deficiency and oral contraceptives. $J$. Amer, med. Ass., 214, 105-108.

Streiff, R. R., and Greene, B. (1970). Drug inhibition of folate conjugase. In Proceedings XIIIth International Congress of Hematology, Munich, p. 377

Streiff, R. R., and Rosenberg, I. H. (1967). Absorption of polyglutamic folic acid. J. clin. Invest., 46, 1121.

Swendseid, M. E., Bird, O. D. Brown, R. A and Bethell, F. H. (1947). Metabolic function of pteroylglutamic acid and its hexaglutamyl conjugate. II. Urinary excretion studies on normal persons. Effect of a conjugase inhibitor. J. Lab. clin. Med., 32, 23-41.

Turner, J. B., and Hughes, D. E. (1962). The absorption of some B-group vitamins by surviving rat intestine preparations. Quart. J. exp. Physiol., 47, 107-133.

Wakisaka, G. (1968). Problems in post-operative patients wit digestive disease. Blind-loop syndrome with megaloblaste anaemia. Gastroent. jap., 3, 109-000.

Waxman, S., Corcino, J., and Herbert, V. (1970). Drugs, toxins arf dietary amino acids affecting vitamin $\mathbf{B}_{12}$ folic acid absorption or utilisation. Amer. J. Med., 48, 599-608.

Whitehead, V. M., and Cooper, B. A. (1967). Absorption of unaltered folic acid from the gastro-intestinal tract in man. Brit. J. Haemat., 13, 679-686.

Whitehead, V. M., Pratt, R., Viallet, A., and Cooper, B. A. (1970). Intestinal conversion of folinic acid to 5-methyltetrahydrofolate in man. In Proceedings XIIIth Congress, American Society of Hematology, Puerto Rico, p. 96.

Winawer, S. J., Sullivan, L. W., Herbert, V., and Zamcheck, N. (1965). The jejunal mucosa in patients with nutritional folate deficiency and megaloblastic anaemia. New Engl. J. Med., 272, 892-895.

Yoshino, T. (1968a). The clinical and experimental studies on the metabolism of folic acid using tritiated folic acid. I. Absorption tests of tritiated folic acid in man. J. Vitaminol., 14, 21-34.

Yoshino, T. (1968b). The clinical and experimental studies on the metabolism of folic acid using tritiated folic acid. II. The experimental studies on the absorption site and mechanisms of tritiated folic acid in rats. J. Vitaminol., 14, 35-48. 